\title{
Unrestricted somatic stem cells from human umbilical cord blood grow in serum-free medium as spheres Faten Zaibak*1,2, Paul Bello ${ }^{3}$, Jennifer Kozlovski ${ }^{1}$, Duncan Crombie ${ }^{4}$, Haozhi Ang1, Mirella Dottori ${ }^{5}$ and Robert Williamson ${ }^{1,2}$
}

Address: ${ }^{1}$ Department of Paediatrics, The University of Melbourne, Royal Children's Hospital, Victoria, 3052, Australia, ${ }^{2}$ Murdoch Childrens Research Institute, Royal Children's Hospital, Victoria, 3052, Australia, ${ }^{3}$ Stem Cell Sciences Ltd, Babraham Research Campus, Cambridge, CB22 3AT, UK, ${ }^{4} \mathrm{O}$ 'Brien Institute, Melbourne, Victoria, 3065, Australia and ${ }^{5}$ Centre for Neurosciences, Department of Pharmacology, The University of Melbourne, Parkville, Victoria, 3010, Australia

Email: Faten Zaibak* - fzaibak@unimelb.edu.au; Paul Bello - paul.bello@stemcellsciences.com; Jennifer Kozlovski - jkozlovski@hotmail.com; Duncan Crombie - dcrombie@unimelb.edu.au; Haozhi Ang - alexang@asia.com; Mirella Dottori - mdottori@unimelb.edu.au; Robert Williamson - r.williamson@unimelb.edu.au

* Corresponding author

Published: 15 December 2009

BMC Biotechnology 2009, 9:101 doi:10.1I86/|472-6750-9-101
Received: 2 March 2009

Accepted: 15 December 2009

This article is available from: http://www.biomedcentral.com/I472-6750/9/10 I

(c) 2009 Zaibak et al; licensee BioMed Central Ltd.

This is an Open Access article distributed under the terms of the Creative Commons Attribution License (http://creativecommons.org/licenses/by/2.0), which permits unrestricted use, distribution, and reproduction in any medium, provided the original work is properly cited.

\begin{abstract}
Background: Human umbilical cord blood-derived unrestricted somatic stem cells (USSCs), which are capable of multilineage differentiation, are currently under investigation for a number of therapeutic applications. A major obstacle to their clinical use is the fact that in vitro expansion is still dependent upon fetal calf serum, which could be a source of pathogens. In this study, we investigate the capacity of three different stem cell culture media to support USSCs in serum-free conditions; HESCGRO ${ }^{\text {TM }}$, PSM and USSC growth medium ${ }^{A C F}$. Our findings demonstrate that USSCs do not grow in HESCGRO ${ }^{\mathrm{TM}}$ or PSM, but we were able to isolate, proliferate and maintain multipotency of three USSC lines in USSC growth medium ${ }^{A C F}$.

Results: For the first one to three passages, cells grown in USSC growth medium ACF proliferate and maintain their morphology, but with continued passaging the cells form spherical cell aggregates. Upon dissociation of spheres, cells continue to grow in suspension and form new spheres. Dissociated cells can also revert to monolayer growth when cultured on extracellular matrix support (fibronectin or gelatin), or in medium containing fetal calf serum. Analysis of markers associated with pluripotency (Oct4 and Sox2) and differentiation (FoxA2, Brachyury, Goosecoid, Nestin, Pax6, Gata6 and Cytokeratin 8) confirms that cells in the spheres maintain their gene expression profile. The cells in the spheres also retain the ability to differentiate in vitro to form cells representative of the three germline layers after five passages.
\end{abstract}

Conclusions: These data suggest that USSC growth medium ${ }^{A C F}$ maintains USSCs in an undifferentiated state and supports growth in suspension. This is the first demonstration that USSCs can grow in a serum- and animal component-free medium and that USSCs can form spheres. 


\section{Background}

Human umbilical cord blood contains a subset of stem cells that can differentiate into cells representative of all three germline layers [1-4]. We follow Kögler, the first to describe the multilineage capacity of these cells in vivo, in calling them "unrestricted somatic stem cells" (USSCs) [1]. A number of studies demonstrate the therapeutic potential of USSCs in bone healing, as accessory cells to reduce graft-versus-host disease, in the repair of myocardial infarcts and as vehicles for gene therapy $[1,3,5-8]$.

Although USSCs are rare compared to haematopoietic stem cells in cord blood, they can be expanded rapidly to yield large numbers of cells for study or transplantation. Culturing of USSCs depends on growth in medium containing a high concentration of specific batches of fetal calf serum. When cultured in fetal calf serum, USSCs form an adherent monolayer, do not require a feeder layer, and can be cultured without differentiating or losing their proliferative capacity.

Before USSCs can be used therapeutically, a method for large scale amplification of cells under Good Manufacturing Practice (GMP) conditions is necessary, preferably using defined medium free of xenobiotic components. Fetal calf serum contains undefined factors, which may vary from batch to batch, and that may activate or inhibit stem cell differentiation. The growth of cells in defined medium not only reduces variability, but also eliminates the need for costly and time consuming fetal calf serum batch testing. Additionally, medium that is free of nonhuman products reduces concerns about transmission of infectious cross-species pathogens (such as prions or zoonosis), and possible immunogenic responses to nonhuman proteins [9-11].

Here we investigate the capacity of three different stem cell culture media HEScGRO ${ }^{\mathrm{mm}}$, PSM and USSC growth medi$\mathrm{um}^{\mathrm{ACF}}$ to enable maintenance of USSCs in serum-free conditions.

PSM is of interest as it contains Sphingosine-1-phosphate (S1P) and platelet-derived growth factor (PDGF), factors known to enable the survival and proliferation of human embryonic stem (hES) cells in an undifferentiated state for a prolonged period of time $[12,13]$.

S1P is a bioactive sphingolipid present in serum that binds to its own G protein-coupled receptors, sphingosine-1-phosphate receptor 1 to $5\left(\mathrm{~S} 1 \mathrm{P}_{(1-5)}\right)$, and activates various intracellular signaling pathways depending on the cell type [14-18]. S1P regulates key biological processes such as cell proliferation, motility, migration and survival in both adult and embryonic stem cell types [13,19-21].
PDGF is a growth factor, also present in serum, that is widely described as a potent mitogen [22]. PDGF is comprised of homo- and hetero-dimeric isoforms of polypeptide chains A, B, C and D [23,24]. The response of a cell to a given isoform of PDGF is dependent on the signaling pathways activated by the two platelet-derived growth factor receptors (PDGFR- $\alpha$ and PDGFR- $\beta$ ), and the capacity of the cell to respond to these signals [25-27].

HEScGRO $^{\mathrm{TM}}$ is a commercial serum- and animal component-free, defined medium known to support the growth and pluripotency maintenance of hES cells. The media contains FGF2 (basic FGF) that, like PDGF, has been reported as having proliferative and differentiation effects on various cell types [28], and figures quite prominently in numerous other adult [29], or embryonic-derived stem cell media formulations [30].

\section{Results}

USSCs form spheres in USSC growth medium ACF

We have analyzed the growth of USSCs in three serumfree media formulations; HEScGRO, PSM and USSC growth medium ${ }^{A C F}$. Figures $1 \mathrm{~A}$ clearly demonstrate that cells cultured in HEScGRO and PSM do not grow, whereas cells grown in USSC growth medium ${ }^{\mathrm{ACF}}$ proliferate at the same rate as cells grown in stem cell proliferation medium containing $30 \%$ fetal calf serum.

However, after one to three passages in USSC growth medium $^{\text {ACF }}$ cells start to form small clusters, which become tight spheres after a further 24 hours (Figure 1B). These spheres are initially heterogeneous in shape, but with continued culturing, rounded spheres with defined borders are observed. Seven days after their first appearance, the size of the spheres varies. Figure $1 \mathrm{C}$ shows that the majority of spheres $(64 \%)$ are small in diameter $(<120$ $\mu \mathrm{m}), 31 \%$ are medium $(120-240 \mu \mathrm{m})$ and the remaining spheres $(5 \%)$ are large $(>240 \mu \mathrm{m})$. The smallest sphere observed was $30 \mu \mathrm{m}$, and the largest was $475 \mu \mathrm{m}$.

Figure 1D shows that the spheres can be mechanically dissociated and can reform spheres upon culturing in USSC growth medium ${ }^{\mathrm{ACF}}$. Evidence of proliferation was observed as spheres could be passaged and new spheres were observed to form.

As the culturing of stem cells as spheres is important for a number of applications, we set out to confirm whether USSCs could form spheres using one of the standard sphere formation methods $[31,32]$. Using the serum-free hanging drop method, we cultured cells either in USSC growth medium ${ }^{\mathrm{ACF}}$, or stem cell proliferation media without fetal calf serum. Figure 2A shows that cells grown in stem cell proliferation media without fetal calf serum in the presence or absence of bFGF do not form spheres, but 
A

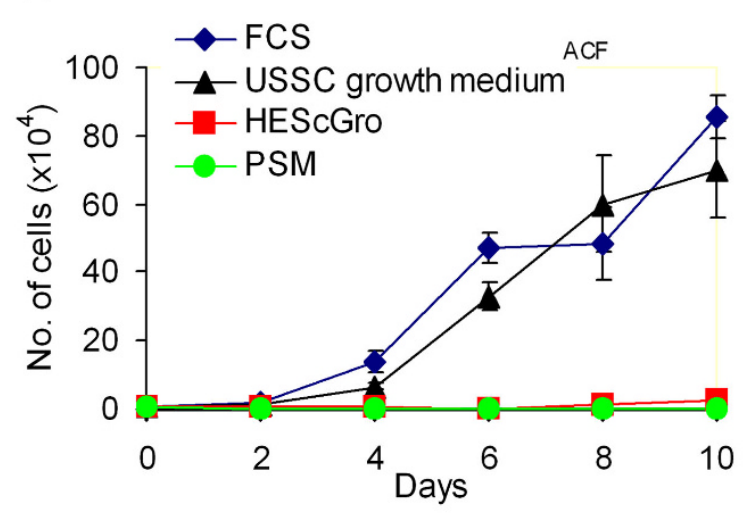

C

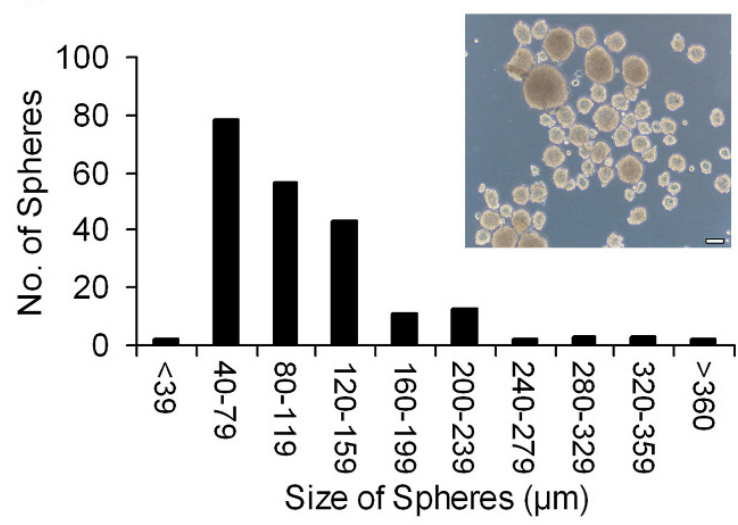

B
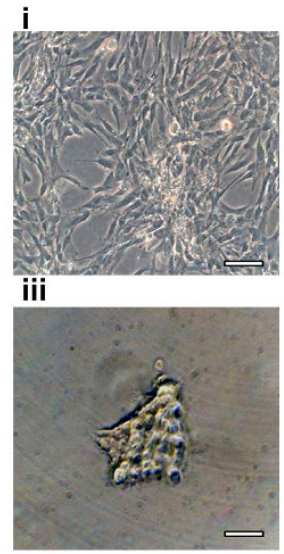

D

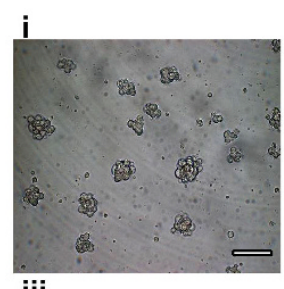

iii

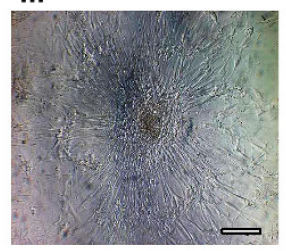

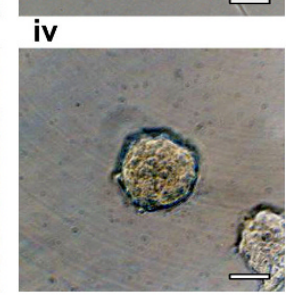

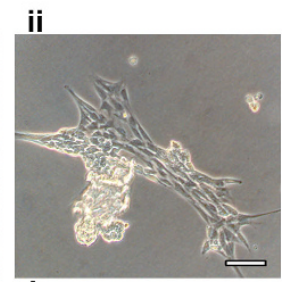

ii

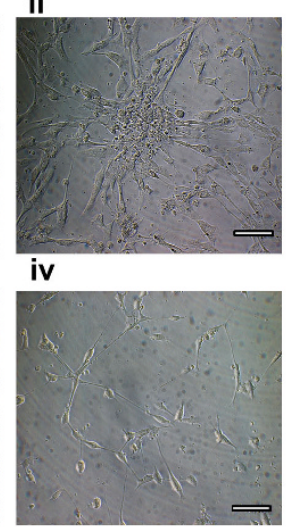

Figure I

Derivation and maintenance of spheres. A, Growth kinetics of USSCs cultured in stem cell proliferation medium, HESc-

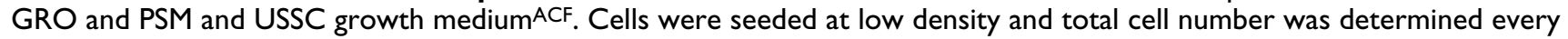
two days. B, Time course of the formation of spheres. i, USSCs in stem cell proliferation medium; ii-iv, USSCs in USSC growth medium ${ }^{A C F}$; ii, after three passages USSCs begin to cluster; iii, within 24 hours of formation, clusters detach from the surface; iv, with continued culturing, clusters increase in size and have defined boundaries. (Magnification, $\times 200$; scale bar is $100 \mu \mathrm{m}$ ) C, Size of spheres on day seven. (Magnification, $\times 100$; scale bar is $100 \mu \mathrm{m}$ )D, Growth of spheres after mechanical dissociation and re-plating on extracellular matrix-coated and non-ECM-coated surfaces; $\mathbf{i}$, clusters of cells continue to grow in USSC growth medium ${ }^{A C F}$; ii, dissociated spheres can grow as an adherent monolayer on fibronectin and collagen-coated surfaces in USSC growth medium ${ }^{A C F}$; iii, dissociated spheres can grown as an adherent monolayer on gelatin-coated surfaces in USSC growth medium ACF; iv, in the absence of mechanical dissociation, spheres cultured in stem cell proliferation media grow as an adherent monolayer. (Magnification, $\times 200$; scale bar is $100 \mu \mathrm{m}$ ).

cells grown in USSC growth medium ${ }^{\mathrm{ACF}}$ always form spheres. There also appears to be a differential effect on the morphology of the sphere depending on whether bFGF is used, in that spheres derived using bFGF are smaller, but tighter, and have less of a halo.

To determine their structure, spheres were serially sectioned and stained with haematoxylin and eosin. Figure 2B shows representative images of a serial section of a sphere. The cells in the spheres appear homogenous in size and morphology and $48 \%$ of the spheres also contained cavities.
Altogether, these data suggest that USSC growth mediu$\mathrm{m}^{\mathrm{ACF}}$ enables USSC proliferation, that this growth occurs simultaneously with the loss of the cells' ability to adhere to plastic, and that these non-adherent cells can continue to grow in suspension as spheres.

\section{USSC-derived spheres can revert to monolayer growth}

The ability of mechanically dissociated spheres to revert to monolayer growth and continue to proliferate was studied after culture in USSC growth medium ${ }^{\mathrm{ACF}}$ on fibronectin or gelatin coated surfaces, or in the presence of stem cell proliferation media containing fetal calf serum. Figure 
A
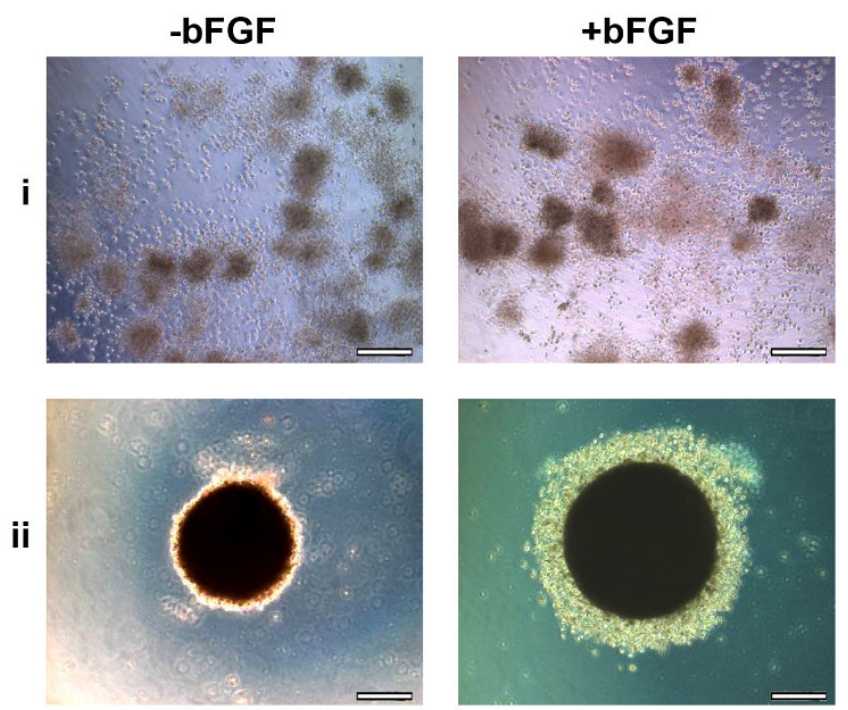

B

\section{Serial sections through a single sphere}

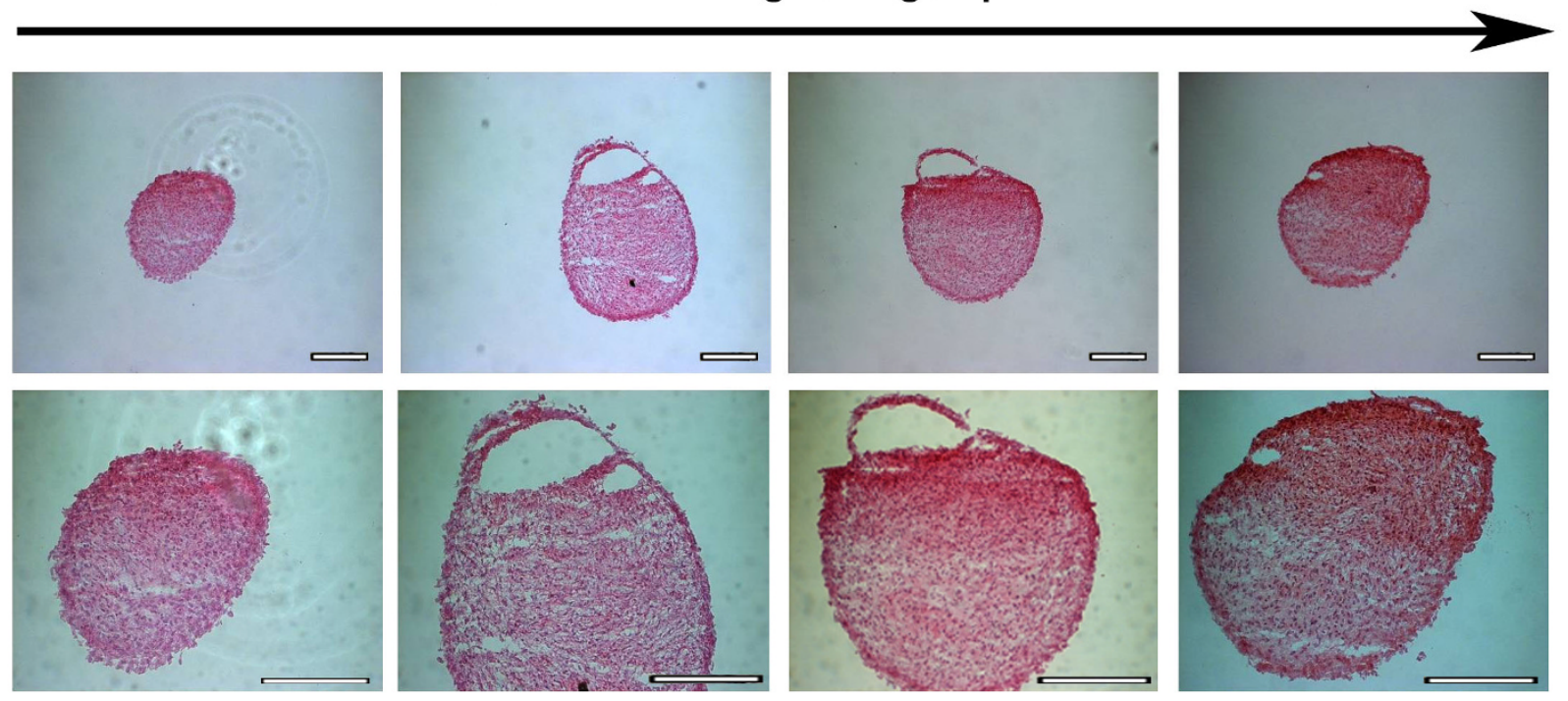

\section{Figure 2}

Characterisation of spheres. A, Morphology of spheres seven days after seeding at high density $\left(\mathrm{I} \times 10^{4} \mathrm{cells} / 30 \mu \mathrm{l}\right)$ as hanging drops in the presence or absence of bFGF in: $\mathbf{i}$, stem cell proliferation medium without fetal calf serum; or ii, USSC growth medium ACF. (Magnification, $\times 200$; scale bar is $100 \mu \mathrm{m}$ ) B, Serial sections of spheres stained with haematoxylin and eosin, generated by culturing in USSC growth medium ${ }^{A C F}$ for seven days at both $\times 200$ and $\times 400$ magnification; scale bar is 100 $\mu \mathrm{m}$. 
$1 \mathrm{D}$ shows that the cells from the spheres re-adhere and morphologically resemble the parental USSCs in the presence of fetal calf serum, or when the surface is coated with extracellular matrix proteins. These cells were cultured for up to two weeks, during which they were passaged three times and expanded up to six-fold. This confirms that cells within the spheres, which have been cultured in USSC growth medium ${ }^{\mathrm{ACF}}$, can revert to monolayer growth and continue to proliferate.

\section{USSCs maintain their multipotentiality when cultured as spheres}

To determine if day seven spheres express pluripotencyassociated markers, the expression of Oct4 and Sox 2 was determined by RT-PCR. Figure 3 shows that USSCs grown in adherent culture do not express Oct4, but do express Sox2, and that USSCs grown as spheres maintain this expression profile. In view of recent reports questioning accurate detection of Oct4 mRNA expression [33], we confirmed that the primers used in this study do not bind to Oct4B (isoform 2) and are specific to the cDNA of the nuclear-localized Oct4A (isoform 1). We also confirmed

A

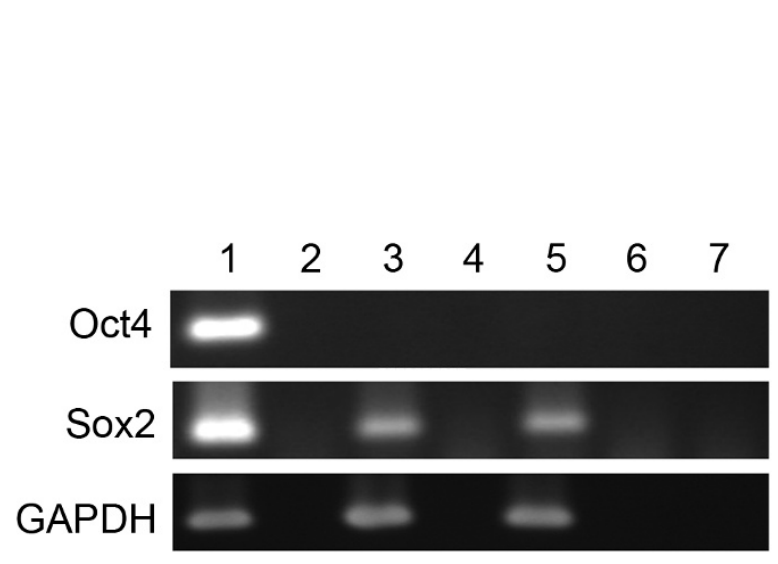

this result using antibody staining. The antibody staining clearly detects nuclear-localized Oct4 in hES cells, but expression could not be detected in USSCs nor seven day spheres (Figure 4).

To determine if the cells in the spheres initiate a differentiation program, we analysed markers associated with commitment of stem cells. Figures 3 and 5 show there is no change in the expression profile of markers associated with ectodermal (Pax6 and Nestin), mesodermal (Brachyury and Goosecoid) and endodermal (FoxA2, Cytokeratin 8 and Gata6) differentiation in day seven spheres when compared to USSCs. This expression profile is also maintained after five passages as determined by RT-PCR for Sox2, Pax6, Gata6, and Brachyury (Figure 6).

\section{Spheres can be differentiated to show expression of markers representative of the three germline layers}

To confirm that the differentiation capacity of the cells in the spheres had been maintained; seven day spheres were dissociated and incubated in lineage-specific differentiation medium. Figure 7 shows that the cells within the
B

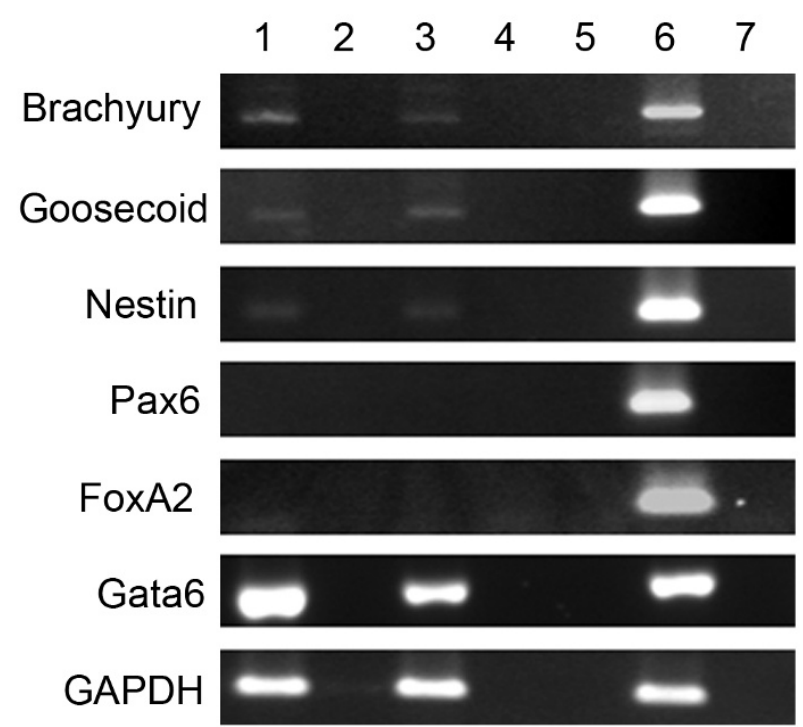

\section{Figure 3}

Gene expression profile seven days after sphere formation. A, RT-PCR for pluripotency-associated genes. RT-PCR shows an absence of Oct4 gene expression in both USSCs and seven day spheres, yet demonstrates expression of the another pluripotency-associated marker Sox2. Lane I, hES cells; Lane 2, RT-negative control of the hES cells; Lane 3, USSCs; Lane 4, RT-negative control of the USSCs; Lane 5, day seven spheres; Lane 6, RT-negative control of the day seven spheres; and Lane 7, water control. B, RT-PCR of genes representative of the three germline layers show that day seven spheres maintain the same expression profile as adherent USSCs. Lane I, USSCs; Lane 2, RT-negative of the USSCs; Lane 3, day seven spheres; Lane 4, RT-negative for the day seven spheres; Lane 5, water control; Lane 6, positive control, spontaneously differentiated hES cells; Lane 7, RT-negative of the spontaneously differentiated hES cells. The house keeping gene GAPDH was used as a positive control. 


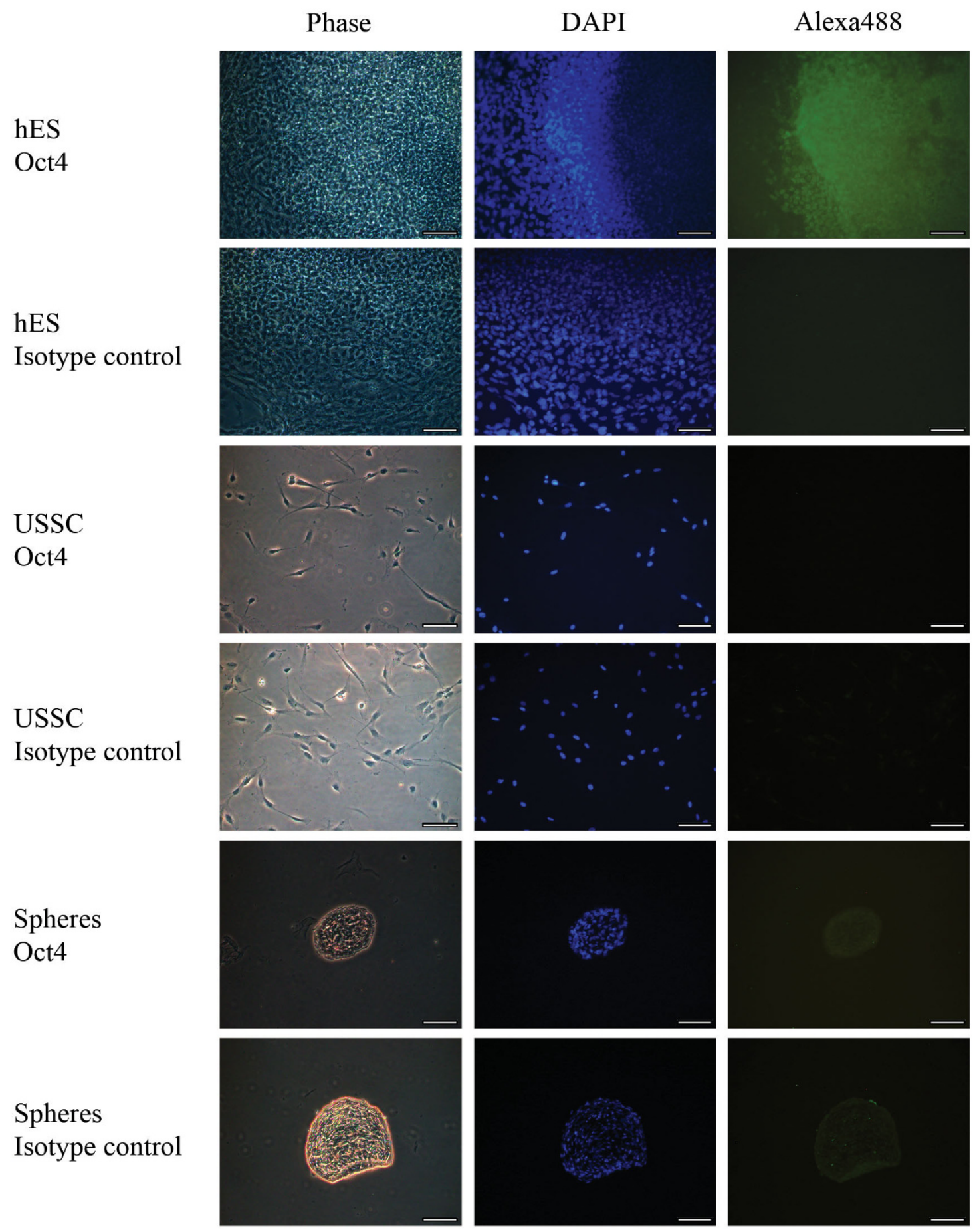

\section{Figure 4}

Oct4 staining on USSC-derived spheres. Representative microscopy images of seven day spheres fixed and stained with an Oct4 antibody (Alexa488; green) and counter stained with 4, 6-diamidino-2-phenylindole (DAPI; blue). As a positive control, the nuclear localisation of the Oct4 antibody was confirmed in hES cells. USSCs were also probed to confirm the Oct4 status of the starting cell population. The respective negative isotype control images are also shown. USSCs and seven day spheres do not express Oct4 at the protein level. (Magnification, $\times 200$; scale bar is $100 \mu \mathrm{m}$ ). 
A
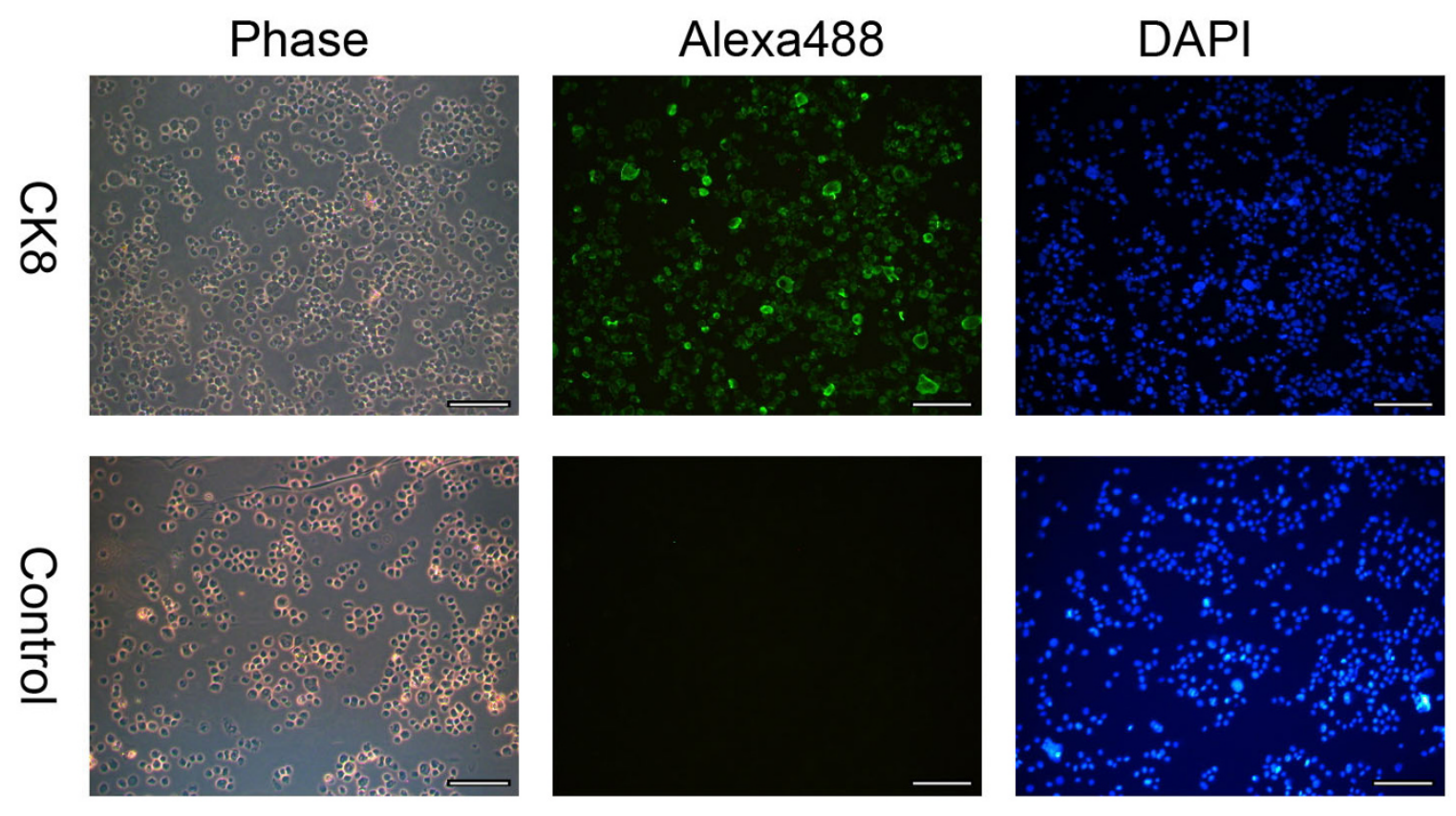

B
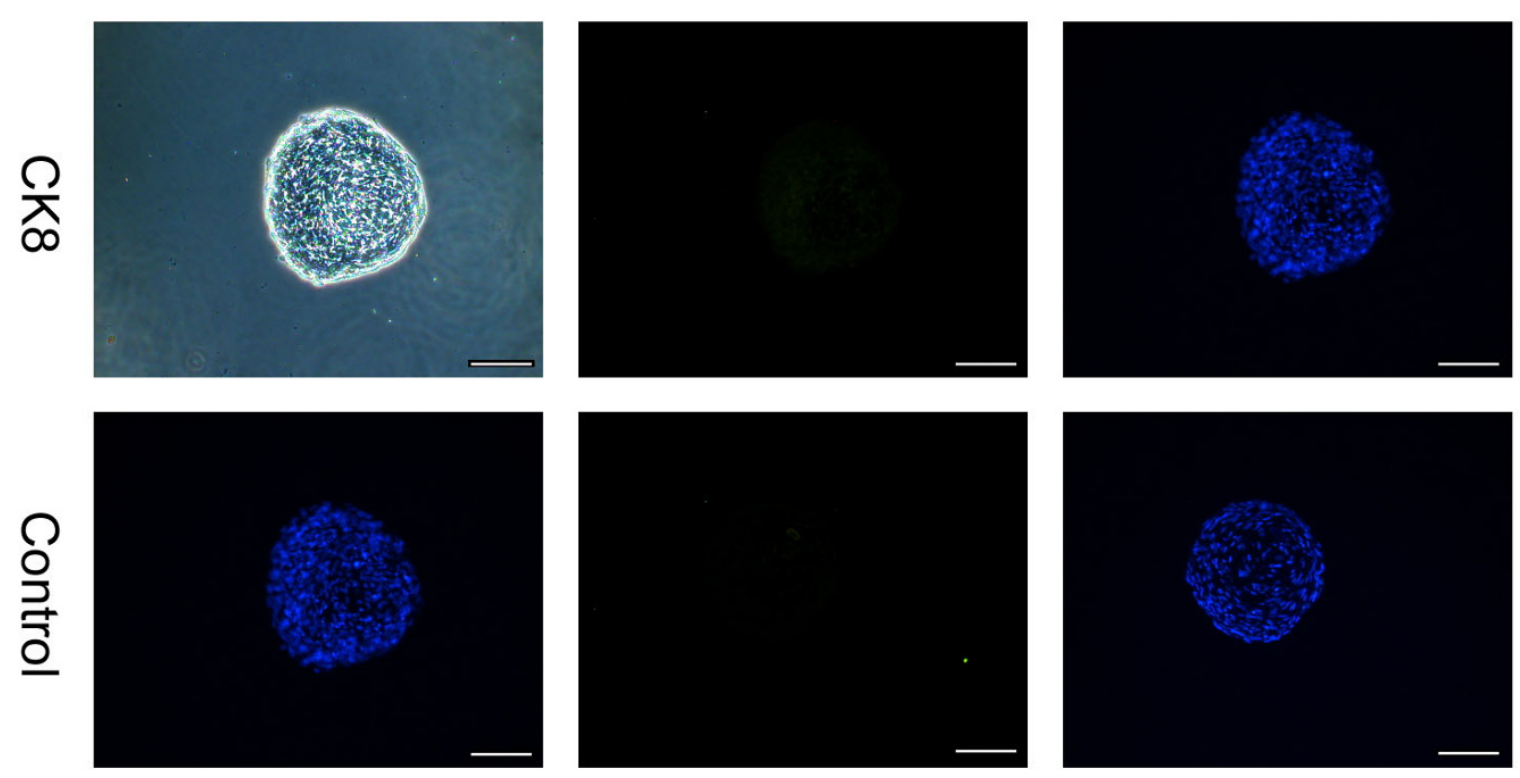

\section{Figure 5}

Cytokeratin 8 staining on USSC-derived spheres. A, As a positive control for CK8 expression, primary human bronchial epithelial (I6HBEI40-) cells were stained. B, Representative microscopy images of seven day spheres fixed, sectioned and stained with a Cytokeratin 8 (CK8) antibody (Alexa488; green) and counter stained with 4, 6-diamidino-2-phenylindole (DAPI; blue). The respective negative isotype control images are also shown. (Magnification $\times 200$; scale bar is $100 \mu \mathrm{m}$.) 
spheres maintain the ability to differentiate and express markers representative of the three germline layers. Cells expressing neuronal-specific $\beta$-tubulin III (a marker of ectodermal cells), that stain positive for mineralization as detected by Alizarin Red S staining (a marker of mesodermal cells) and express epithelial-specific surfactant protein-C (a marker of endodermal cells) were all observed. The differentiation capacity of the cells is also maintained after five passages in USSC growth medium ${ }^{\mathrm{ACF}}$ (Figures 8 and 9).

\section{Discussion}

With the goal of deriving clinically safe USSCs, we aimed to culture established USSCs in the serum- and animal component-free medium, USSC growth medium ${ }^{\mathrm{ACF}}$. We observe that USSCs continue to proliferate in USSC growth medium ${ }^{\mathrm{ACF}}$, but after one to three passages, the cells aggregate and grow in suspension as spheres. We show that spheres can be dissociated and can continue to grow for five passages, as long as they are dissociated before the sphere becomes cystic. We also show the spheres can revert to monolayer growth when provided with extracellular matrix support or when plated in medium containing fetal calf serum. Cells passaged in USCC growth medium ${ }^{\mathrm{ACF}}$ maintained their gene expression profile as judged by Sox2, Brachyury, Pax6 and Gata6

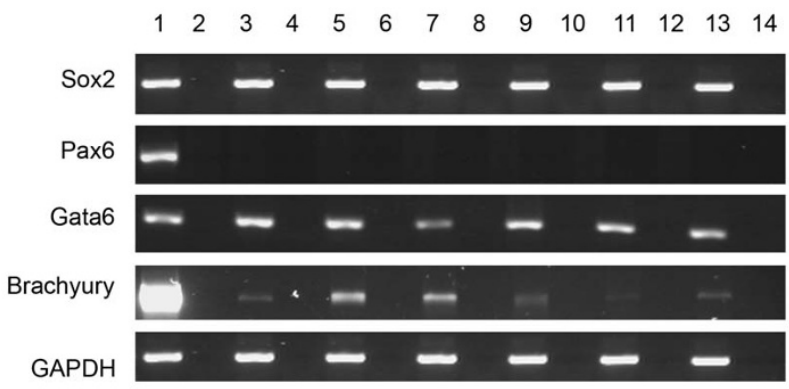

\section{Figure 6}

Gene expression profile of three different stem cell lines after five passages in USSC growth mediumACF. RT-PCR for pluripotency (Sox2), ectodermal (Pax6), mesodermal (Gata6) and endodermal (Brachyury), associated genes after five passages in USSC growth medium ${ }^{A C F}$. The house keeping gene GAPDH was used as a positive control. Lane I, hES cells; Lane 2, RT-negative control for hES cells. Lanes 3-8 are USSCs cultured in fetal calf serum: Lane 3, USSC Line I; Lane 4, RT-negative control for USSC Line I; Lane 5, USSC Line 2; Lane 6, RT-negative control for USSC Line 2; Lane 7, USSC Line 3; and Lane 8, RT-negative control for USSC Line 3. Lanes 9-I4 are USSCs passaged five times in USSC growth mediumACF: Lane 9, USSC Line I; Lane 10, RT-negative control for USSC Line I; Lane II, USSC Line 2; Lane I2, RT-negative control for USSC Line 2; Lane 13, USSC Line 3; and Lane I4, RT-negative control for USSC Line 3. expression. Cells also maintained their capacity to form bone-like Alizarin red positive cells, SPC positive epithelial cells and $\beta$-tubulin III positive neuronal cells after directed differentiation. This is the first report of a serumfree medium that enables proliferation of USSCs and the first to report that USSCs can be grown in suspension as spheres, without losing their differentiation capacity.

Growing stem cells as spheres has been the initial step in a wide range of differentiation studies, as well as studies in pharmacogenetics, teratogenesis and tumourigenesis [32,34-42]. Sphere formation can be facilitated by growing cells in specific medium (both serum-free and complete), on non-adherent plates, in bioreactors, in agar, as hanging drops, or by centrifugation $[31,36,43]$. Despite these many studies, the significance of sphere formation is yet to be fully understood. While it could reflect a nonspecific event, it could alternatively be an active process essential for continued development and differentiation. The differentiation potential of stem cells in spheres appears to be dependent upon the starting cell population and the medium in which the spheres are cultured. For example, human bone marrow stromal cells can be conditioned to give rise to neurospheres, which lose their stem cell characteristics and become committed to neuronal development [40].

To characterize the spheres derived in this study further, we investigated a number of markers expressed in pluripotent cells and in cells representative of the three germline layers. We show that Oct4-negative USSCs give rise to spheres, and that cells within these spheres continue to express Sox2. Analysis of differentiation-associated markers (Nestin, Pax6, Brachyury, Goosecoid, FoxA2 and Gata6) by RT-PCR confirms that cells cultured in USSC growth medium ${ }^{\mathrm{ACF}}$ do not initiate a program of differentiation.

The ability of USSC spheres to maintain an undifferentiated state makes them distinct from other spheres derived from cells capable of multilineage differentiation. The most studied of these spheres are embryoid bodies, defined as spherical clusters of both pluripotent and committed stem cells that can organize in a developmentalspecific manner [35,42,44-48]. Unlike embryoid bodies, USSC spheres do not commit to any differentiation programs when cultured in USSC growth medium ${ }^{\mathrm{ACF}}$.

The cavities detected in USSC spheres are also distinct from cavities observed in embryoid bodies. The formation of cavities in embryoid bodies is an active process, characterized by a thickening of the wall around the cavity, and associated with the expression of endodermal-specific markers such as Cytokeratin 8 [49,50]. While USSC spheres can have cavities, we show that the cells surround- 
A
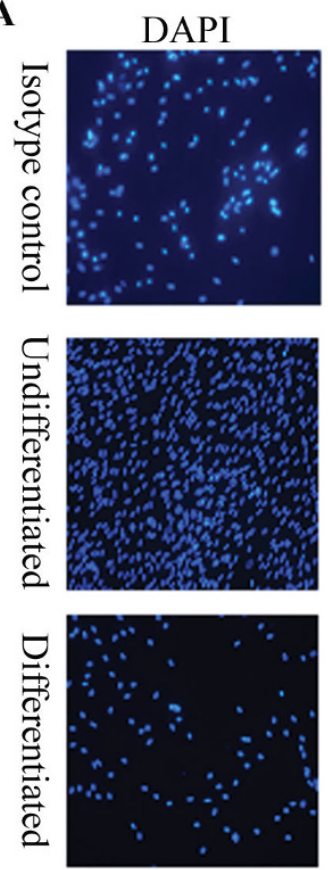

Alexa568
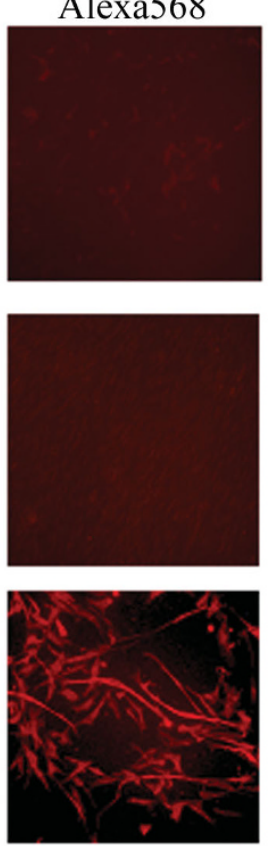
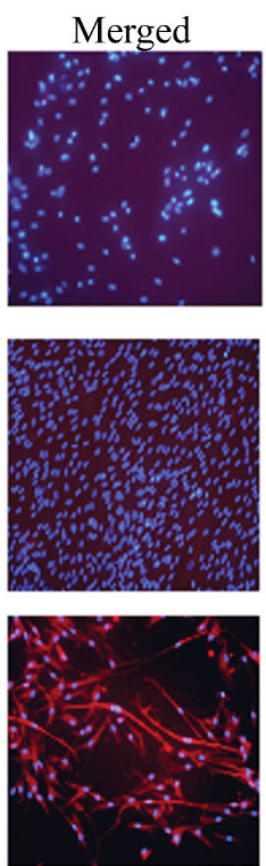

B

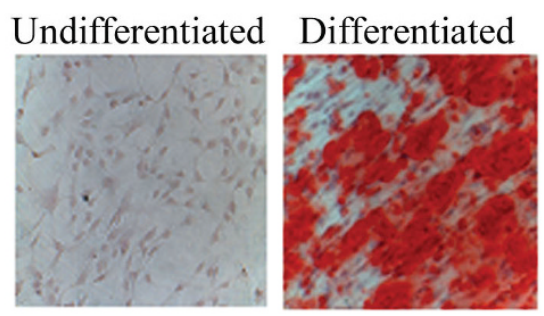

C

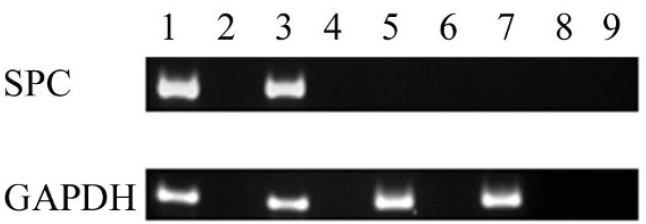

\section{Figure 7}

Differentiation of spheres into neuronal, bone and epithelial-like cells. Seven days after sphere formation, cells were dissociated and plated on coated plates, as described in the materials and methods. The next day, cells were cultured in differentiation medium. A, Neuronal differentiation was confirmed by staining with a neuronal-specific $\beta$-tubulin III antibody (Alexa568; red) and counter stained with 4, 6-diamidino-2-phenylindole (DAPI; blue). B, Bone differentiation cultures were stained with Alizarin Red S to test for mineral deposition. C, Epithelial differentiation was confirmed by RT-PCR of SPC. Lane I, human bronchial epithelial cell line, I6HBEI4o-; Lane 2, RT-negative control of the human bronchial epithelial cell line; Lane 3, differentiated spheres; Lane 4, RT-negative control of the differentiated spheres; Lane 5, undifferentiated spheres; Lane 6, RT-negative control of the undifferentiated spheres; Lane 7, USSC Line I; Lane 8, RT-negative control of the USSC Line I; and Lane 9, water control.

ing the cavities and the outer layer of the sphere do not express the endodermal marker Cytokeratin 8.

As marker analysis is insufficient to infer function, we also analyzed the ability of the cells to respond to differentiation cues. When USSC spheres are reverted to monolayer growth and differentiated in lineage-specific medium, surfactant protein C-positive epithelial-like cells, $\beta$-tubulin III-positive neuronal-like cells and Alizarin Red S-positive bone-like cells are observed after one to five passages, confirming that the cells in the spheres are still multipotent. However, derivation of spheres from a single cell and validation that each cell in the sphere retains these stem cell properties is still essential.

\section{Conclusions}

We present a new method to grow USSCs in suspension without losing their multi-lineage differentiation capacity in short term assays. The ability to culture these cells in a three-dimensional spherical structure in a defined animal component-free environment is a first step towards improving protocols for tissue engineering, and expansion of these cells in vitro.

Although there are a number of serum-free media marketed for culturing other types of stem cells, USSC growth medium ${ }^{A C F}$ is unique because it enables the short term expansion of USSCs in suspension, the formation of spheres, and the maintenance of the multilineage differentiation capacity of USSCs. Suspension culturing of cells facilitates large scale expansion, but we note that it will still be necessary to validate the genetic stability and safety of cells after long term cell growth before they can be used therapeutically. The latter is also heightened by two recent publications using human cord to derive iPSC $[51,52]$ which would further expand USSC multipotentiality for therapeutic utility, including drug discovery.

\section{Methods \\ Isolation and culture of USSCs}

Cord blood was collected with informed consent from mothers undergoing elective Caesarean section. The pro- 
A
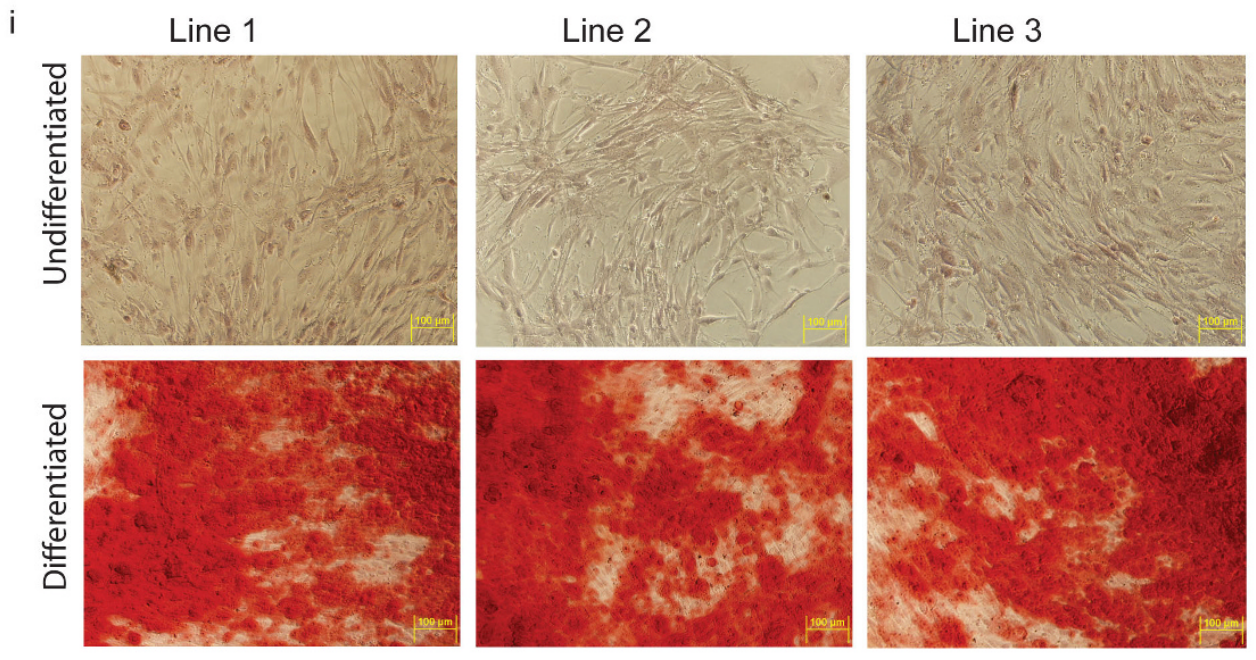

ii
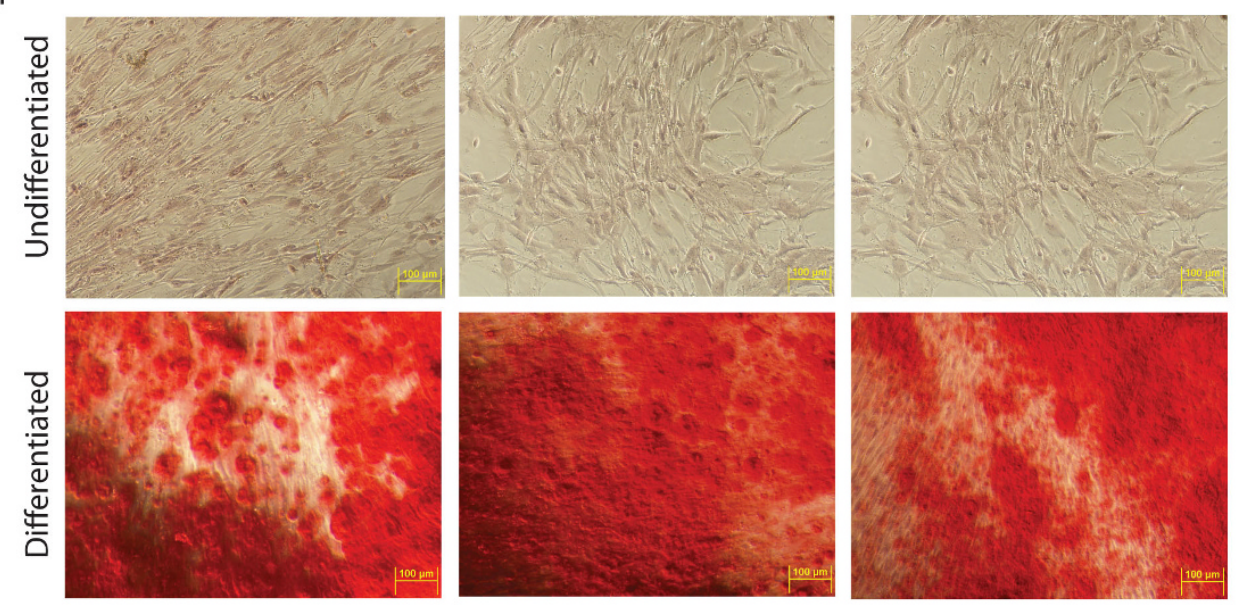

B

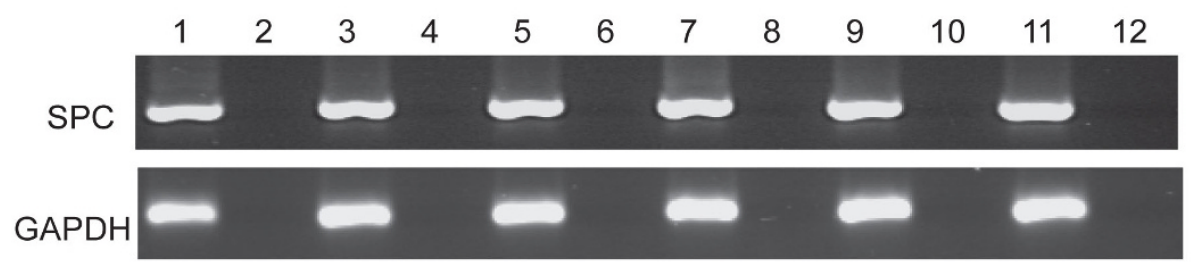

Figure 8

Differentiation capacity of three different stem cell lines after five passages in USSC growth mediumACF. After five passages in USSC growth medium ${ }^{A C F}$, cells were dissociated and plated on coated plates, as described in Materials and Methods. The next day, differentiation medium was added. A, Bone differentiation cultures were stained with Alizarin Red $\mathrm{S}$ to test for mineral deposition. (i) USSC cultured in fetal calf serum; and (ii) cells cultured in USSC growth medium ${ }^{A C F}$ for five passages. B, Epithelial differentiation was confirmed by RT-PCR of SPC of cells differentiated in Small Airway Growth Medium. Lane I-6 USSCs passaged in fetal calf serum: Lane I, USSC Line I; Lane 2, RT-negative control for USSC Line I; Lane 3, USSC Line 2; Lane 4, RT-negative control for USSC Line 2; Lane 5, USSC Line 3; and Lane 6, RT-negative control for USSC Line 3. Lanes 7-I 2 USSCs passaged five times in USSC growth medium ACF: Lane 7, USSC Line I; Lane 8, RT-negative control for USSC Line I; Lane 9, USSC Line 2; Lane 10, RT-negative control for USSC Line 2; Lane II, USSC Line 3; and Lane I2, RT-negative control for USSC Line 3. 
tocol was approved by the University of Melbourne and the Royal Women's Hospital Human Ethics Review Committees. After the delivery of the baby, the cord was clamped and the blood was collected from the umbilical cord vein in bags containing $21 \mathrm{ml}$ citrate phosphate dextrose (Macopharma, Mouvaux, France).

The USSC lines were successfully generated as described by Kögler et al. [1]. Briefly, the mononuclear cell fraction was separated on a Ficoll gradient (density $1.077 \mathrm{~g} / \mathrm{cm}^{3}$, GE Healthcare, Uppsala, Sweden) at $400 \mathrm{~g}$ for $25 \mathrm{~min}$ followed by lysis of erythrocytes in ammonium chloride buffer $(0.14 \mathrm{M}$ ammonium chloride, $0.25 \mathrm{mM}$ ethylenediamine-tetra-acetic acid (EDTA), $10 \mathrm{mM}$ tris(hydroxymethyl)aminomethane pH7.4) and two washing steps in calcium- and magnesium-free phosphate-buffered saline (PBS), $\mathrm{pH}$ 7.4. To initiate the growth of the adherent USSC colonies, the mononuclear cell suspension was plated at $2 \times 10^{6} \mathrm{cells} / \mathrm{cm}^{2}$ in initiation medium containing low-glucose Dulbecco's Modified Eagle's Medium (Lonza, Walkersville, MD, USA) supplemented with $30 \%$ fetal calf serum (Hyclone, Logan, UT, USA), 10-7 M dexamethasone (Sigma, St Louis, MO, USA), $100 \mathrm{U} / \mathrm{ml}$ penicillin (Invitrogen, Chadsworth, CA, USA), $0.1 \mathrm{mg} / \mathrm{ml}$ streptomycin (Invitrogen) and $2 \mathrm{mM}$ Ultraglutamine (Lonza).

Cells were incubated at $37^{\circ} \mathrm{C}$ in $5 \% \mathrm{CO}_{2}$ in a humidified incubator. Every five days, the non-adherent fraction was removed and fresh medium was added. Initiation medium was used until the first colonies appeared or for a maximum of three weeks. Expansion of the cells was carried out using initiation medium without dexamethasone (stem cell proliferation medium). After reaching 80\% confluency, the cells were subcultured using $0.25 \%$ trypsin/EDTA (Invitrogen), and replated at a 1:2 dilution in stem cell proliferation medium. Low passage cells were frozen down at $1 \times 10^{6}$ cells $/ \mathrm{ml}$ in $10 \%$ dimethyl sulfoxide (Sigma) and 50\% fetal calf serum (Hyclone). For each experiment, cells were thawed and used before they reached passage ten.

The phenotype of the lines was as previously published $[1,8]$. All the lines were negative for CD34, CD24, CD31, CD45 and MHCII, and positive for CD44, CD71 and MHCI. The multilineage capacity of the lines was confirmed by differentiation into cells representative of the three germline layers.

\section{Culturing in serum-free medium}

Cells were cultured in three different media; PSM, HESc$\mathrm{GRO}^{\mathrm{TM}}$ or USSC growth mediumACF. PSM; is a basal medium containing low-glucose Dulbecco's Modified Eagle Medium (Cambrex BioScience), $100 \mathrm{U} / \mathrm{ml}$ penicillin $/ 0.1 \mathrm{mg} / \mathrm{ml}$ streptomycin (Invitrogen), and $2 \mathrm{mM}$ Ult- raglutamine (Cambrex BioScience) with or without 10 $\mu \mathrm{M}$ of S1P (Biomol, Exeter, UK) and $20 \mathrm{ng} / \mathrm{ml}$ PDGF (Peprotech, NJ, USA) as described in Pebay et al., 2007. HEScGRO $^{\text {тM }}$ (Millipore) was prepared according to the manufactures instructions. USSC growth medium ${ }^{A C F}$ (Stem Cell Sciences, UK) was supplemented with $10 \mathrm{ng} /$ $\mathrm{ml}$ recombinant human basic fibroblast growth factor (bFGF) (Millipore) before use.

Cells were seeded at $5.2 \times 10^{4} \mathrm{cells} / \mathrm{cm}^{2}$ and split $1: 2$ when they reached $80 \%$ confluency. However, after one to three passages, the cells cultured in USSC growth medium ${ }^{\mathrm{ACF}}$ grew as non-adherent spheres without requiring any intervention to initiate aggregation. To maintain sphere proliferation, spheres were dissociated mechanically or using $0.25 \%$ trypsin/EDTA every four days, and allowed to reform in USSC growth medium ${ }^{\text {ACF }}$. Cells were cultured for five passages and then characterized further. If spheres are not dissociated within a week they become cystic and resistant to disaggregation by trypsinization.

Spheres were also generated using the hanging drop formation [31]. Briefly, a total of $1 \times 10^{4}$ cells were placed in $30 \mu \mathrm{l}$ of USSC growth medium ${ }^{\text {ACF }}$ (plus or minus bFGF), or in stem cell proliferation medium without fetal calf serum (plus or minus bFGF), and dropped onto the inside of a Petri dish lid. Drops were incubated upside down in a Petri dish that contained PBS in the base to prevent evaporation.

To confirm the cells could revert to monolayer growth, dissociated and non-dissociated spheres were grown in stem cell proliferation medium that contains fetal calf serum. To determine if the cells could adhere while cultured in USSC growth medium ${ }^{\mathrm{ACF}}$, dissociated and nondissociated spheres were plated in Petri dishes coated with $1 \%$ gelatin (Sigma) in PBS, or $10 \mu \mathrm{g} / \mathrm{ml}$ fibronectin (Becton Dickinson, Franklin Lakes, NJ, USA).

\section{Differentiation assays}

Multipotency of the USSCs and the spheres was confirmed by differentiation into bone-, neuronal- and epithelial-like cells. Spheres were dissociated with $0.25 \%$ trypsin/EDTA (Invitrogen) and plated on $0.1 \%$ gelatin (Sigma) in PBS-coated plates overnight before induction.

To test for mesodermal differentiation capacity of the cells, bone differentiation assays were performed. Cells were plated at $7 \times 10^{3}$ cells $/ \mathrm{cm}^{2}$ cultured for ten days in stem cell proliferation medium containing $10^{-7} \mathrm{M}$ dexamethasone (Sigma), $10 \mathrm{mM}$ glycerol-6-phosphate (Sigma) and $50 \mu \mathrm{g} / \mathrm{ml}$ ascorbic acid (Sigma) as described by Jaiswal et al. [53]. Medium was replaced every five days. To confirm successful mineralisation, cells were fixed for ten minutes with $70 \%$ ethanol at $4{ }^{\circ} \mathrm{C}$, and stained for ten 
A
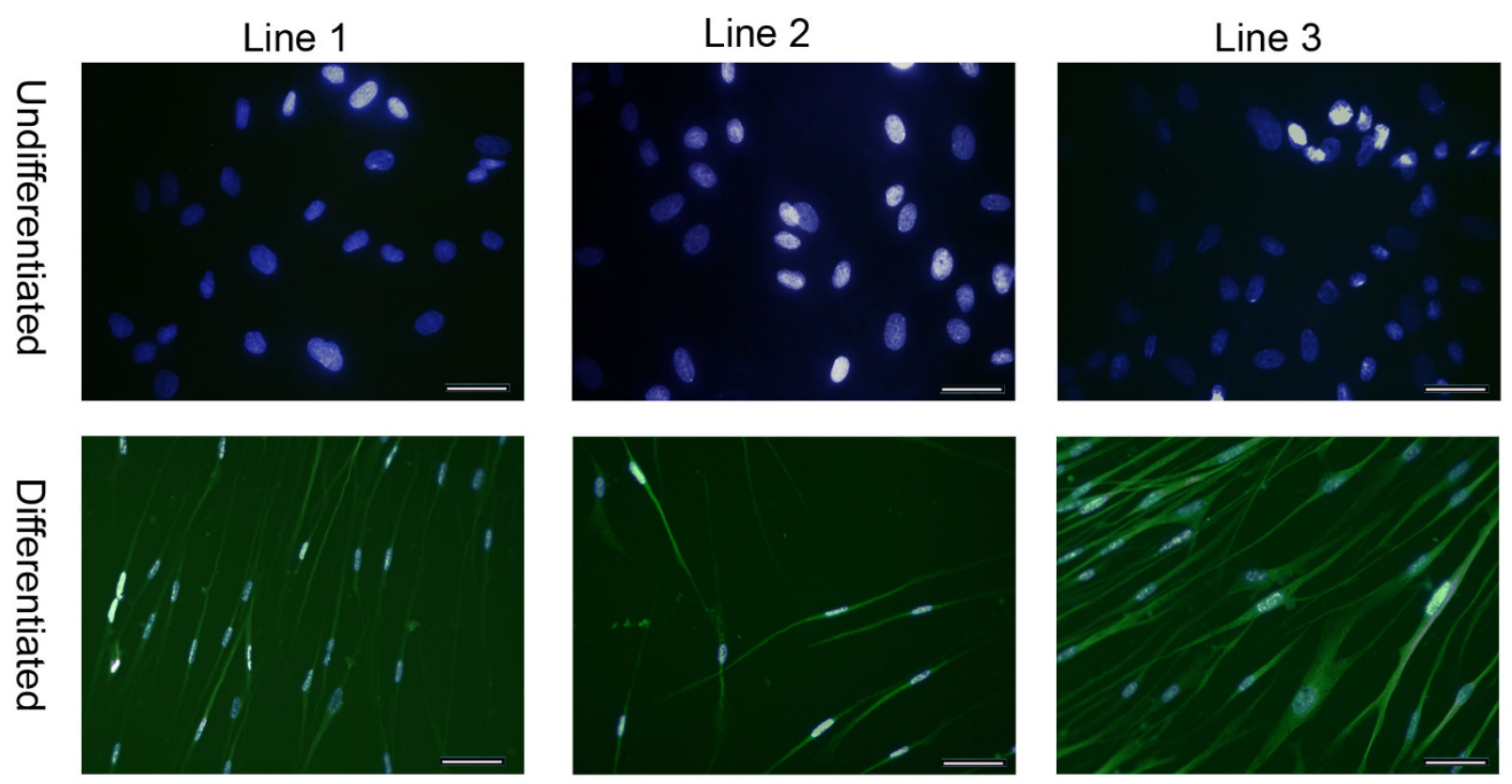

B
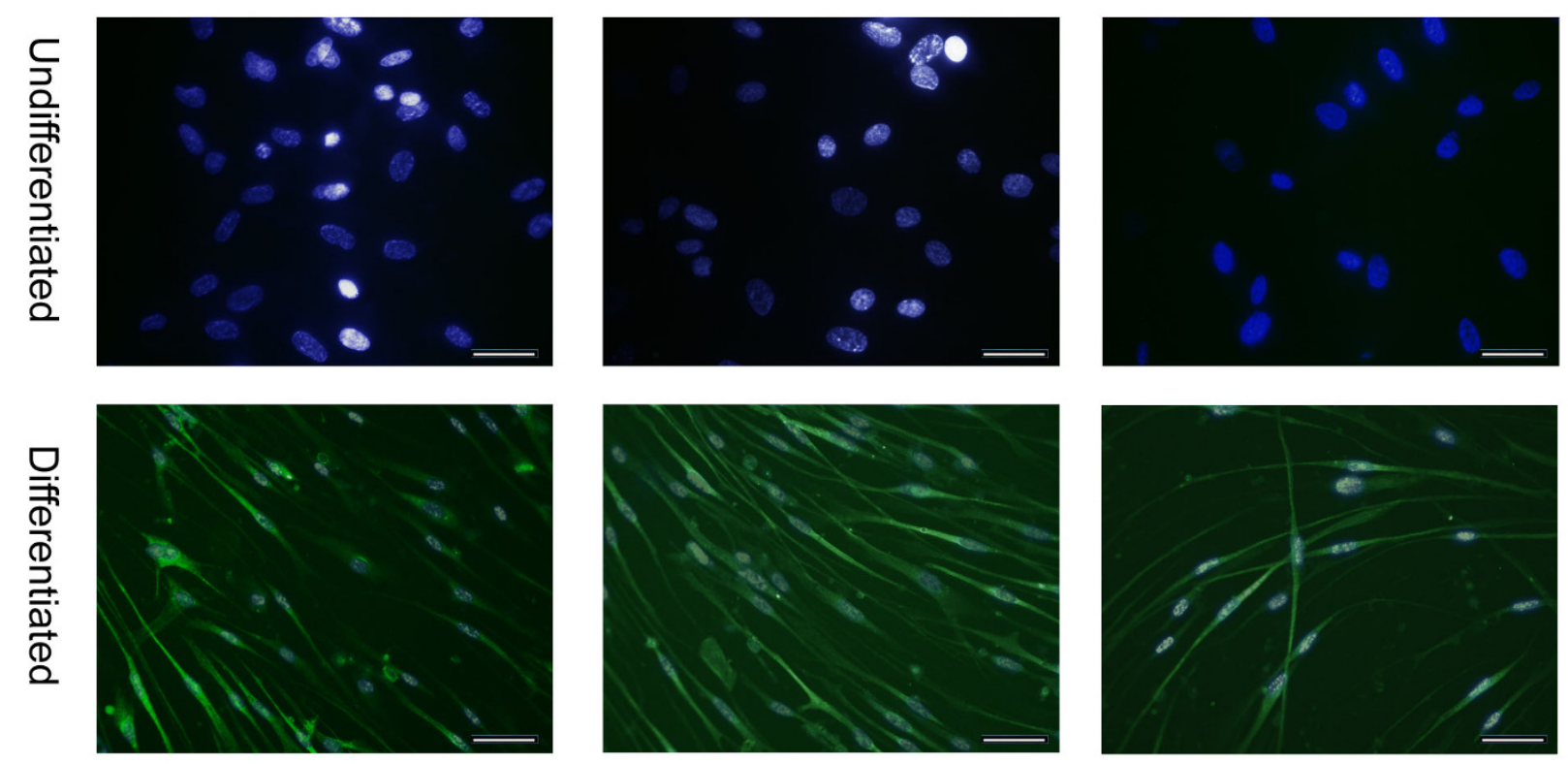

\section{Figure 9}

Neuronal differentiation capacity of three different stem cell lines after five passages in USSC growth mediu$\mathbf{m}^{\mathbf{A C F}}$. Neuronal differentiation was confirmed by staining with a neuronal-specific $\beta$-tubulin III antibody (Alexa488). A, USSCs cultured in fetal calf serum; and B, USSCs cultured in USSC growth medium ${ }^{\text {ACF }}$ for five passages. DAPI (blue) and Alexa488 (green) merged images shown. (Magnification $\times 200$; scale bar is $100 \mu \mathrm{m}$ ). 
minutes with $1 \%$ Alizarin Red S (Sigma) in distilled water, $\mathrm{pH}$ 4.2. The cells were then washed five times in distilled water, layered in PBS (minus calcium and magnesium) and phase images were captured as described below.

To demonstrate the neuronal differentiation capacity of the cells, the differentiation protocol described by Dottori et al. was adapted for USSCs [54]. Briefly, cells were plated on $10 \mu \mathrm{g} / \mathrm{ml}$ poly-D-lysine (Sigma), $10 \mu \mathrm{g} / \mathrm{ml}$ fibronectin (Becton Dickinson) coated glass coverslips and cultured in neural basal medium consisting of Neurobasal A with $2 \%$ B-27, 1\% insulin-transferrin-selenium-A, $1 \% \mathrm{~N} 2,2$ $\mathrm{mM}$ L-glutamine, $100 \mathrm{U} / \mathrm{ml}$ penicillin and $0.1 \mathrm{mg} / \mathrm{ml}$ streptomycin (all sourced from Invitrogen). Neural basal medium was supplemented with $20 \mathrm{ng} / \mathrm{ml}$ basic fibroblast growth factor (R\&D Systems, Minneapolis, MN, USA) and $20 \mathrm{ng} / \mathrm{ml}$ epidermal growth factor (R\&D Systems) prior to adding to the cells. Media was changed every two to three days, for a total culture period of 12 days at $37^{\circ} \mathrm{C}$ with $5 \% \mathrm{CO}_{2}$ in a humidified incubator. Differentiated cells were fixed in $4 \%$ paraformaldehyde $(\mathrm{BDH}$, Dorset, United Kingdom) for ten minutes at $4{ }^{\circ} \mathrm{C}$ and immunostained overnight with $1 \mu \mathrm{g} / \mathrm{ml}$ of the mouse IgG $_{1}$ antihuman $\beta$-tubulin III (Invitrogen); or $1 \mu \mathrm{g} / \mathrm{ml}$ mouse $\mathrm{IgG}_{1}$ negative isotype control (Dako, Glostrup, Denmark). Cells were stained with $2 \mu \mathrm{g} / \mathrm{ml}$ of the goat anti-mouse
Alexa568 or 488 IgG secondary antibody (Invitrogen) and counterstained with $0.5 \mu \mathrm{g} / \mathrm{ml}$ of 4, 6-diamidino-2-phenylindole (DAPI, Sigma) mounted in Vectashield (Vector Laboratories, Burlingame, CA, USA). Fluorescent images were captured as described below.

To test for epithelial differentiation capacity of the cells, cells were grown in Small Airway Growth Medium (SAGM, Lonza) as described by Berger et al. [55]. Cells were seeded at $5 \times 10^{4} / \mathrm{cm}^{2}$ in stem cell proliferation medium the day before the addition of SAGM and then were differentiated for eight days and medium was changed after four days. Differentiation was assessed by nested RT-PCR for Surfactant Protein C (SPC). RNA extraction and PCR protocols are detailed below. The PCR conditions for SPC were as described by Berger et al. [55], and the human bronchial epithelial cell line, 16HBE140, was used as a positive control for SPC expression [56].

\section{Reverse transcription-polymerase chain reaction}

Total RNA was isolated from 5-10 × $10^{5}$ trypsinized USSCs and from mechanically dislodged pools of spheres using RNeasy Mini Kit (Qiagen, Germantown, MD, USA) and RNase-Free DNase I Set (Qiagen) according to the manufacturer's instruction, and quantified using a NanoDrop 1000 Spectrophotometer. Reverse transcripts were pre-

Table I: Summary of conditions and primers used for RT-PCR.

\begin{tabular}{|c|c|c|c|c|c|}
\hline Genes & \multicolumn{2}{|c|}{ Primer Sequences (5'-3') } & Cycles & Size (bp) & Annealing Temperature $\left({ }^{\circ} \mathrm{C}\right)$ \\
\hline \multicolumn{6}{|c|}{ Pluripotency-associated markers } \\
\hline \multirow[t]{2}{*}{ Oct4 } & $\mathrm{F}$ & TCTCGCCCCСTCCAGGT & 30 & 218 & 53 \\
\hline & $\mathrm{R}$ & GCCCCACTCCAACCTGG & & & \\
\hline \multirow[t]{2}{*}{ Sox2 } & $\mathrm{F}$ & GGCAGCTACAGCATGATGCAGGACC & 34 & 130 & 60 \\
\hline & $\mathrm{R}$ & CTGGTCATGGAGTTGTACTGCAGG & & & \\
\hline \multicolumn{6}{|c|}{ Endodermal-associated markers } \\
\hline \multirow[t]{2}{*}{ FoxA2 } & $\mathrm{F}$ & GGGAGCGGTGAAGATGGA & 38 & 89 & 55 \\
\hline & $\mathrm{R}$ & TCATGTTGCTCACGGAGGAGTA & & & \\
\hline \multirow[t]{2}{*}{ Gata6 } & $\mathrm{F}$ & GAGTGAGAGAAGATGGAAGGG & 38 & 250 & 55 \\
\hline & $\mathrm{R}$ & CGCACATGAAATCTGGATGTGG & & & \\
\hline \multicolumn{6}{|c|}{ Ectodermal-associated markers } \\
\hline \multirow[t]{2}{*}{ Nestin } & $\mathrm{F}$ & CAGCTGGCGCACCTCAAGATG & 30 & 209 & 55 \\
\hline & $\mathrm{R}$ & AGGGAAGTTGGGCTCAGGACTGG & & & \\
\hline \multirow[t]{2}{*}{ Pax6 } & $\mathrm{F}$ & AACAGACACAGCCCTCACAAACA & 30 & 275 & 55 \\
\hline & $\mathrm{R}$ & CGGGAACTTGAACTGGAACTGAC & & & \\
\hline \multicolumn{6}{|c|}{ Mesodermal-associated markers } \\
\hline \multirow{2}{*}{ Brachyury } & $\mathrm{F}$ & GAACCAGCACCCTGTGTCCAC & 38 & 608 & 57 \\
\hline & $\mathrm{R}$ & GCCACGACAAAAAGTCACTGC & & & \\
\hline \multirow[t]{2}{*}{ Goosecoid } & $\mathrm{F}$ & CTCAACCAGCTGCACTGTC & 38 & 322 & 55 \\
\hline & $\mathrm{R}$ & GTCAGCTGTCCGAGTCCAAATC & & & \\
\hline \multicolumn{6}{|c|}{ Control-associated markers } \\
\hline \multirow[t]{2}{*}{ GAPDH } & $\mathrm{F}$ & ATGGAGAAGGCTGGGGCTC & 28 & 196 & 55 \\
\hline & $\mathrm{R}$ & AAGTTGTCATGGATGACCTTG & & & \\
\hline
\end{tabular}


pared from 500 ng of total RNA using the SuperScript III First-Strand Synthesis System (Invitrogen), and cDNA was amplified using the Taq PCR Core Kit (Qiagen). Briefly, $0.4 \mu \mathrm{M}$ of of forward and reverse primers, $0.25 \mathrm{U}$ of Taq, $1 \times$ Q-solution, 1× PCR buffer containing $1.5 \mu \mathrm{M}$ of $\mathrm{MgCl}_{2}, 200 \mu \mathrm{M}$ of dNTPs and $2 \mu \mathrm{l}$ of cDNA were used. Table 1 contains the primer sequences, amplification conditions and expected RT-PCR product sizes of all genes investigated. The PCR conditions were as follows: $94^{\circ} \mathrm{C}$ for 2 minutes; $28-38$ cycles of $94^{\circ} \mathrm{C}$ for 30 seconds, 30 seconds annealing at $51-61^{\circ} \mathrm{C}, 72^{\circ} \mathrm{C}$ for 1 minute; and a final extension step at $72^{\circ} \mathrm{C}$ for 2 minutes.

\section{In situ hybridization}

The spheres were fixed in $4 \%$ paraformaldehyde (BDH) for ten minutes at $4{ }^{\circ} \mathrm{C}$ and incubated overnight in $20 \%$ sucrose in PBS with calcium and magnesium (Invitrogen) at $4{ }^{\circ} \mathrm{C}$. Cells were embedded in optimal cutting temperature compound (OCT, Tissue Tek, Japan) and stored at $70^{\circ} \mathrm{C}$. Serial sections were cut $(10 \mu \mathrm{m})$ using a Microm HM 550 cryostat (Carl Zeiss) and placed on Superfrost (Menzel-Glaser, GmbH, Fisher Scientific) slides. Haematoxylin and eosin (Sigma) staining was performed using standard conditions. To characterize the spheres, sections were stained with $4.5 \mu \mathrm{g} / \mathrm{ml}$ mouse anti-human Cytoker-

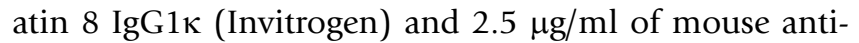
human Oct4 IgG2 $\beta$ (Santa Cruz, CA, USA). Slides were washed in PBS (with calcium and magnesium) with $0.1 \%$ Tween 20 (PBT), blocked for 2 hours with PBT containing $10 \%$ fetal calf serum (Invitrogen), and stained with the primary antibody or the appropriate IgG isotype control (Dako) overnight at $4{ }^{\circ} \mathrm{C}$. Cells were washed three times in PBT and stained with goat anti-mouse Alexa488 secondary antibody (Invitrogen) for 1 hour at room temperature and then washed three times in PBT. Before analysis, slides were counterstained with DAPI (Sigma) $0.5 \mu \mathrm{g} / \mathrm{ml}$ for five minutes at room temperature, then mounted with Vectashield (Vector Laboratories).

\section{Microscopy}

Microscopy was performed on a fluorescent inverted microscope (Carl Zeiss AG, Oberkochen, Germany). Images were captured using Axiom photo system (Carl Zeiss).

\section{List of Abbreviations}

bFGF: basic fibroblast growth factor; DAPI: 4',6-diamidino-2-phenylindole; hES cell: embryonic stem cell; Oct4: Octamer-4 homeodomain transcription factor; RT-PCR: reverse transcription PCR; and USSC: unrestricted somatic stem cell.

\section{Authors' contributions}

FZ, RW, HA and PB conceived and designed the experiment. FZ and RW provided financial support. PB and DC developed the USSC growth medium ${ }^{\mathrm{ACF}}$. FZ developed the USSCs lines. $\mathrm{FZ}, \mathrm{JK}, \mathrm{MD}$ and $\mathrm{HA}$ performed all the experiments. FZ, and $\mathrm{PB}$ performed all the data analysis. All authors were involved in data interpretation. All authors contributed to the manuscript writing and approved the final draft.

\section{Acknowledgements}

We thank the New Zealand Cystic Fibrosis Association, Australian Cystic Fibrosis Research Trust, University of Melbourne, and a group of generous donors that initiated the establishment of this research program. Special thanks to: Professor Gesine Kögler, who advised us on the creation of the USSC line; Jacqui Johnson and Jenny Greenhalgh for reagent support; Dr Alice Pebay for providing PSM; and Pei Tian and Dr Caitlin Filby for their technical support.

\section{References}

I. Kögler G, Sensken S, Airey JA, Trapp T, Muschen M, Feldhahn N, Liedtke S, Sorg RV, Fischer J, Rosenbaum C, et al: A new human somatic stem cell from placental cord blood with intrinsic pluripotent differentiation potential. J Exp Med 2004, 200(2): $123-135$.

2. Fallahi-Sichani M, Soleimani M, Najafi SM, Kiani J, Arefian E, Atashi A In vitro differentiation of cord blood unrestricted somatic stem cells expressing dopamine-associated genes into neuron-like cells. Cell Biol Int 2007, 3 I (3):299-303.

3. Jager M, Degistirici O, Knipper A, Fischer J, Sager M, Krauspe R: Bone healing and migration of cord blood-derived stem cells into a critical size femoral defect after xenotransplantation. J Bone Miner Res 2007, 22(8): I224-1233.

4. Sensken S, Waclawczyk S, Knaupp AS, Trapp T, Enczmann J, Wernet $P$, Kogler G: In vitro differentiation of human cord bloodderived unrestricted somatic stem cells towards an endodermal pathway. Cytotherapy 2007, 9(4):362-378.

5. Kim BO, Tian H, Prasongsukarn K, Wu J, Angoulvant D, Wnendt S, Muhs A, Spitkovsky D, Li RK: Cell transplantation improves ventricular function after a myocardial infarction: a preclinical study of human unrestricted somatic stem cells in a porcine model. Circulation 2005, I I 2(9 Suppl):196-I04.

6. Chan SL, Choi M, Wnendt S, Kraus M, Teng E, Leong HF, Merchav S: Enhanced in vivo homing of uncultured and selectively amplified cord blood CD34+ cells by cotransplantation with cord blood-derived unrestricted somatic stem cells. Stem Cells 2007, 25(2):529-536.

7. Ghodsizad A, Niehaus M, Koegler G, Martin U, Wernet P, Bara C Khaladj N, Loos A, Makoui M, Thiele J, et al.: Transplanted human cord blood derived unrestricted somatic stem cells improve left-ventricular function and prevent left-ventricular dilation and scar formation after acute myocardial infarction. Heart 2009, 95(I):27-35

8. Zaibak F, Kozlovski J, Vadolas J, Sarsero JP, Williamson R, Howden SE: Integration of functional bacterial artificial chromosomes into human cord blood-derived multipotent stem cells. Gene Therapy 2009, 16(3):404-4I4.

9. Selvaggi TA, Walker RE, Fleisher TA: Development of antibodies to fetal calf serum with arthus-like reactions in human immunodeficiency virus-infected patients given syngeneic lymphocyte infusions. Blood 1997, 89(3):776-779.

10. Martin MJ, Muotri A, Gage F, Varki A: Human embryonic stem cells express an immunogenic nonhuman sialic acid. Nature Medicine 2005, I I(2):228-232.

II. Chachques JC, Herreros J, Trainini J, Juffe A, Rendal E, Prosper F, Genovese J: Autologous human serum for cell culture avoids the implantation of cardioverter-defibrillators in cellular cardiomyoplasty. Int J Cardiol 2004, 95(Suppl I):S29-33.

12. Inniss K, Moore H: Mediation of apoptosis and proliferation of human embryonic stem cells by sphingosine-I-phosphate. Stem Cells and Development 2006, I 5(6):789-796.

13. Pebay A, Wong RC, Pitson SM, Wolvetang EJ, Peh GS, Filipczyk A Koh KL, Tellis I, Nguyen LT, Pera MF: Essential roles of sphingosine-I-phosphate and platelet-derived growth factor in the 
maintenance of human embryonic stem cells. Stem Cells 2005 23(10): $154 \mid-1548$.

14. Ikeda H, Satoh H, Yanase M, Inoue Y, Tomiya T, Arai M, Tejima K, Nagashima K, Maekawa H, Yahagi N, et al.: Antiproliferative property of sphingosine I-phosphate in rat hepatocytes involves activation of Rho via Edg-5. Gastroenterology 2003, I 24(2):459-469.

15. Payne SG, Milstien S, Spiegel S: Sphingosine-I-phosphate: dual messenger functions. FEBS letters 2002, 53 I (I):54-57.

16. Van Brocklyn JR, Lee MJ, Menzeleev R, Olivera A, Edsall L, Cuvillier O, Thomas DM, Coopman PJ, Thangada S, Liu CH, et al.: Dual actions of sphingosine-I-phosphate: extracellular through the Gi-coupled receptor Edg-I and intracellular to regulate proliferation and survival. J Cell Biol I998, I42(I):229-240.

17. Ishii I, Fukushima N, Ye X, Chun J: Lysophospholipid receptors: signaling and biology. Annu Rev Biochem 2004, 73:321-354.

18. Donati C, Cencetti F, Nincheri P, Bernacchioni C, Brunelli S, Clementi E, Cossu G, Bruni P: Sphingosine I-phosphate mediates proliferation and survival of mesoangioblasts. Stem Cells 2007, 25(7): $17|3-17| 9$

19. Kimura T, Boehmler AM, Seitz G, Kuci S, Wiesner T, Brinkmann V, Kanz L, Mohle R: The sphingosine I-phosphate receptor agonist FTY720 supports CXCR4-dependent migration and bone marrow homing of human CD34+ progenitor cells. Blood 2004, I 03(I 2):4478-4486.

20. Xue X, Cai Z, Seitz G, Kanz L, Weisel KC, Mohle R: Differential effects of $G$ protein coupled receptors on hematopoietic progenitor cell growth depend on their signaling capacities. Annals of the New York Academy of Sciences 2007, I I 06: I80- 189.

21. Walter DH, Rochwalsky U, Reinhold J, Seeger F, Aicher A, Urbich C, Spyridopoulos I, Chun J, Brinkmann V, Keul P, et al.: Sphingosine- Iphosphate stimulates the functional capacity of progenitor cells by activation of the CXCR4-dependent signaling pathway via the SIP3 receptor. Arteriosclerosis, thrombosis, and vascula biology 2007, 27(2):275-282

22. Wong RC, Tellis I, Jamshidi P, Pera M, Pebay A: Anti-apoptotic effect of sphingosine-I-phosphate and platelet-derived growth factor in human embryonic stem cells. Stem Cells and Development 2007, 16(6):989-1002.

23. Claesson-Welsh L, Heldin $\mathrm{CH}$ : Platelet-derived growth factor. Three isoforms that bind to two distinct cell surface receptors. Acta Oncol 1989, 28(3):33I-334.

24. Uutela M, Lauren J, Bergsten E, Li X, Horelli-Kuitunen N, Eriksson U, Alitalo K: Chromosomal location, exon structure, and vascular expression patterns of the human PDGFC and PDGFC genes. Circulation 200I, 103(18):2242-2247.

25. Escobedo JA, Barr PJ, Williams LT: Role of tyrosine kinase and membrane-spanning domains in signal transduction by the platelet-derived growth factor receptor. Mol Cell Biol 1988, 8(I2):5|26-5|3|.

26. Eriksson A, Siegbahn A, Westermark B, Heldin CH, Claesson-Welsh $\mathrm{L}:$ PDGF alpha- and beta-receptors activate unique and common signal transduction pathways. The EMBO journal 1992, I I(2):543-550.

27. Satoh T, Fantl WJ, Escobedo JA, Williams LT, Kaziro Y: Plateletderived growth factor receptor mediates activation of ras through different signaling pathways in different cell types. Mol Cell Biol 1993, I3(6):3706-37।3.

28. Bottcher RT, Niehrs C: Fibroblast growth factor signaling dur ing early vertebrate development. Endocrine reviews 2005, 26(I):63-77.

29. Ahn HJ, Lee WJ, Kwack K, Kwon YD: FGF2 stimulates the proliferation of human mesenchymal stem cells through the transient activation of JNK signaling. FEBS letters 2009, 583( I 7):2922-2926.

30. Stewart MH, Bendall SC, Bhatia M: Deconstructing human embryonic stem cell cultures: niche regulation of selfrenewal and pluripotency. Journal of Molecular Medicine 2008, 86(8):875-886.

3I. Kurosawa $\mathrm{H}$ : Methods for inducing embryoid body formation: in vitro differentiation system of embryonic stem cells. J Biosci Bioeng 2007, 103(5):389-398.

32. Conley BJ, Young JC, Trounson AO, Mollard R: Derivation, propagation and differentiation of human embryonic stem cells. Int J Biochem Cell Biol 2004, 36(4):555-567.
33. Liedtke S, Enczmann J, Waclawczyk S, Wernet P, Kögler G: Oct4 and its pseudogenes confuse stem cell research. Cell Stem Cell 2007, I:364-366.

34. Wartenberg M, Gunther J, Hescheler J, Sauer H: The embryoid body as a novel in vitro assay system for antiangiogenic agents. Lab lnvest |998, 78(10):|30|-|3|4

35. Itskovitz-Eldor J, Schuldiner M, Karsenti D, Eden A, Yanuka O, Amit $\mathrm{M}$, Soreq $\mathrm{H}$, Benvenisty $\mathrm{N}$ : Differentiation of human embryonic stem cells into embryoid bodies compromising the three embryonic germ layers. Mol Med 2000, 6(2):88-95

36. Layer PG, Robitzki A, Rothermel A, Willbold $E$ : Of layers and spheres: the reaggregate approach in tissue engineering. Trends Neurosci 2002, 25(3): $131-134$

37. Lu D, Li Y, Mahmood A, Wang L, Rafiq T, Chopp M: Neural and marrow-derived stromal cell sphere transplantation in a rat model of traumatic brain injury. J Neurosurg 2002, 97(4):935-940.

38. Seiler A, Visan A, Buesen R, Genschow E, Spielmann H: Improvement of an in vitro stem cell assay for developmental toxicity: the use of molecular endpoints in the embryonic stem cell test. Reprod Toxicol 2004, 18(2):23I-240.

39. Aleksandrova MA, Podgornyi OV, Poltavtseva RA, Panova IG, Sukhikh GT: Structure and cell composition of spheres cultured from human fetal retina. Bull Exp Biol Med 2006, I42(I): I52-I59.

40. Suon S, Yang M, lacovitti L: Adult human bone marrow stromal spheres express neuronal traits in vitro and in a rat model of Parkinson's disease. Brain Res 2006, I I 06(I):46-5I.

4I. Weitzer G: Embryonic stem cell-derived embryoid bodies: an in vitro model of eutherian pregastrulation development and early gastrulation. Handb Exp Pharmacol 2006:2I-5I.

42. Lan L, Cui D, Nowka K, Derwahl M: Stem cells derived from goiters in adults form spheres in response to intense growth stimulation and require thyrotropin for differentiation into thyrocytes. J Clin Endocrinol Metab 2007, 92(9):368I-3688.

43. Ng ES, Davis RP, Azzola L, Stanley EG, Elefanty AG: Forced aggregation of defined numbers of human embryonic stem cells into embryoid bodies fosters robust, reproducible hematopoietic differentiation. Blood 2005, I06(5): I60I-I603.

44. Doetschman TC, Eistetter H, Katz M, Schmidt W, Kemler R: The in vitro development of blastocyst-derived embryonic stem cell lines: formation of visceral yolk sac, blood islands and myocardium. J Embryol Exp Morphol 1985, 87:27-45

45. Abuljadayel IS: Induction of stem cell-like plasticity in mononuclear cells derived from unmobilised adult human peripheral blood. Curr Med Res Opin 2003, 19(5):355-375.

46. Guan K, Nayernia K, Maier LS, Wagner S, Dressel R, Lee JH, Nolte J, Wolf $\mathrm{F}, \mathrm{Li}$ M, Engel W, et al:: Pluripotency of spermatogonial stem cells from adult mouse testis. Nature 2006, 440(7088): II 199-I203.

47. Yu H, Fang D, Kumar SM, Li L, Nguyen TK, Acs G, Herlyn M, Xu X: Isolation of a novel population of multipotent adult stem cells from human hair follicles. Am J Pathol 2006, I68(6): $1879-1888$.

48. Yang X, Qu L, Wang X, Zhao M, Li W, Hua J, Shi M, Moldovan N, Wang H, Dou Z: Plasticity of epidermal adult stem cells derived from adult goat ear skin. Mol Reprod Dev 2007, 74(3):386-396

49. Maye P, Becker S, Kasameyer E, Byrd N, Grabel L: Indian hedgehog signaling in extraembryonic endoderm and ectoderm differentiation in ES embryoid bodies. Mech Dev 2000, 94(I2): $117-132$

50. Conley BJ, Ellis S, Gulluyan L, Mollard R: BMPs regulate differentiation of a putative visceral endoderm layer within human embryonic stem-cell-derived embryoid bodies. Biochem Cell Biol 2007, 85(I): $12 \mid-132$

51. Haase A, Olmer R, Schwanke K, Wunderlich S, Merkert S, Hess C, Zweigerdt R, Gruh I, Meyer J, Wagner S, et al.: Generation of induced pluripotent stem cells from human cord blood. Cell Stem Cell 2009, 5(4):434-44I.

52. Giorgetti A, Montserrat N, Aasen T, Gonzalez F, Rodriguez-Piza I, Vassena R, Raya A, Boue S, Barrero MJ, Corbella BA, et al:: Generation of induced pluripotent stem cells from human cord blood using OCT4 and SOX2. Cell Stem Cell 2009, 5(4):353-357.

53. Jaiswal N, Haynesworth SE, Caplan Al, Bruder SP: Osteogenic differentiation of purified, culture-expanded human mesenchy- 
mal stem cells in vitro. Journal of Cellular Biochemistry 1997, 64(2):295-3I2.

54. Dottori M, Pera MF: Neural differentiation of human embryonic stem cells. Methods Mol Biol 2008, 438:19-30.

55. Berger M, Adams S, Tigges B, Sprague S, Wang XJ, Collins D, McKenna D: Differentiation of umbilical cord blood-derived multilineage progenitor cells into respiratory epithelial cells. Cytotherapy 2006, 8(5):480-487.

56. Cozens AL, Yezzi MJ, Chin L, Simon EM, Finkbeiner WE, Wagner JA, Gruenert DC: Characterization of immortal cystic fibrosis tracheobronchial gland epithelial cells. Proceedings of the National Academy of Sciences of the United States of America 1992, 89(II):5|7|-5|75.

Publish with Biomed Central and every scientist can read your work free of charge

"BioMed Central will be the most significant development for disseminating the results of biomedical research in our lifetime. " Sir Paul Nurse, Cancer Research UK

Your research papers will be:

- available free of charge to the entire biomedical community

- peer reviewed and published immediately upon acceptance

- cited in PubMed and archived on PubMed Central

- yours - you keep the copyright
BioMedcentral 